\title{
Oestrus ovis larvae in nasal cavity of sheep: a case report
}

\author{
I. M. Allaie $\cdot$ Z. A. Wani $\cdot$ A. H. Malik . \\ R. A. Shahardar • M. Zulhuma
}

Received: 21 November 2014 / Accepted: 27 January 2015/Published online: 14 February 2015

(C) Indian Society for Parasitology 2015

\begin{abstract}
The present communication reports the infestation of nasal cavities of sheep by larvae of Oestrus ovis from Kashmir Valley.
\end{abstract}

Keywords Kashmir - Nasal cavities .

Oestrus ovis larvae · Sheep

\section{Introduction}

The larvae of the sheep nasal bot fly, Oestrus ovis are well known parasites in the nasal cavities and frontal sinuses, sometimes also in the maxillary sinuses of domestic sheep, goats and some wild ruminants worldwide, causing the clinical picture known as oestrosis (Zumpt 1965). The viviparous females swarm around the heads of the animals and deposit the larvae from a distance of several centimeters into the nostrils and sometimes also into the eye orbits, in batches of one to several dozen. The larvae then migrate into the nasal cavities and the paranasal sinuses where they develop. The duration of this parasitic portion of the life cycle varies considerably from a few weeks to several months, depending on the season and climatic conditions (Cobbett and Mitchell 1941). Clinical respiratory signs such as seromucous or purulent nasal discharge, frequent sneezing, and dyspnea may severely impair

I. M. Allaie $(\bowtie) \cdot$ Z. A. Wani · R. A. Shahardar Division of Veterinary Parasitology, F.V.Sc. \& A.H, SKUAST-

K, Shuhama Campus (Alusteng), Srinagar 190006, India e-mail: dr.idreesallaie@gmail.com;

idreesmeharaj@skuastkashmir.ac.in

\section{A. H. Malik · M. Zulhuma}

Division of Livestock Product Technology, F.V.Sc. \& A.H, SKUAST-K, Shuhama Campus (Alusteng), Srinagar 190006, India the health of affected animals (Dorchies et al. 1998). O. ovis may be considered a zoonosis (Wall and Shearer 1977). In humans, ophthalmomyiasis, respiratory and non-respiratory infestation is also caused by this fly and is seen in rural areas where small ruminants and humans live in close proximity (Sucilathangam et al. 2013). O. ovis can thrive in different environments and has adapted to the climate prevailing wherever sheep are kept (Horak 1977). Kashmir valley is home to a large variety of parasites. The conducive environment allows the pathogens to grow and pose greatest challenge to economic rearing of livestock. Earlier Shahardar et al. (2001) had reported the occurrence of O. ovis larvae in an abberent site of sheep from Kashmir Valley. The present communication reports the occurence of $O$. ovis larvae in the nasal cavity of sheep.

\section{Materials and methods}

Rams were subjected to antemortem examination before their slaughter at Division of Livestock Production and Technology, FVSc. \& AH., SKUAST-K for sale of meat. The animal's apparently looked healthy with no visible clinical signs. After slaughtering, their nasal cavities were opened and secreened for $O$. ovis. Larvae were collected and brought to Division of Veterinary Parasitology, FVSc. \& AH., SKUAST-K for identification.

\section{Results and discussion}

Based on the morphological features i.e. dark bands on their dorsal surface and spines on the ventral aspect, the larvae were identified as third stage larvae of $O$. ovis (Fig. 1). O. ovis infestation in sheep has been reported from 
Fig. 1 Larvae of Oestrus ovis in nasal cavities of sheep
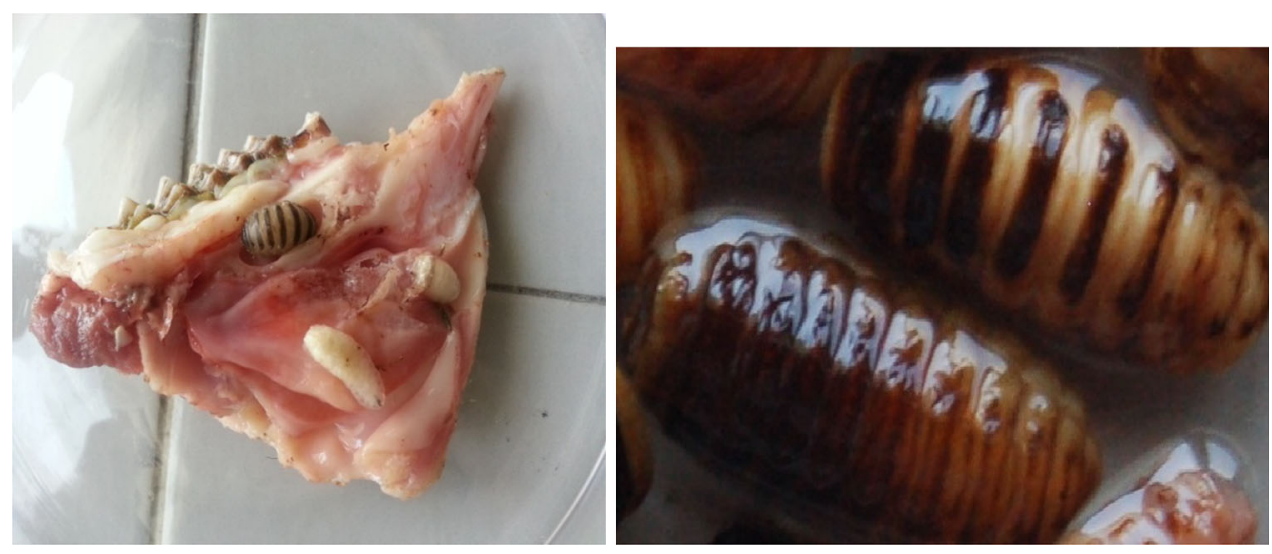

different countries, 33.2-65\% in France (Bergeaud et al. 1994; Dorchies et al. 2000; Jacquiet and Dorchies 2002; Yilma and Dorchies 1991), $71.1 \%$ in Spain (Alcaide et al. 2003), and 55.8-91.0 \% in Italy (Caracappa et al. 2000). In India $48.3 \%$ prevalence of $O$. ovis has been reported (Jagannath et al. 1989). Chhabra and Ruprah (1976) and Gupta (1982) reported 80.90 and $72.40 \%$ small ruminants positive for $O$. ovis larvae in Hissar, Haryana, respectively. In Jammu $88.9 \%$ occurrence of $O$. ovis larvae in goats is on record (12th Annual Report, SKUAST-J). Taniya (2013) reported that $99.16 \%$ sheep heads and $89.16 \%$ goat heads were infested with $O$. ovis larvae in Jammu. Shahardar and Rashid (1998) have reported occurrence of larvae of $O$. ovis in a goat in Kashmir Valley. Shahardar et al. (2001) have also recovered larvae of $O$. ovis from an unusual site i.e. trachea and bronchi of sheep in Kashmir Valley. The small ruminants are let to graze in the open fields and on high land pastures, there are chances of contracting the infestation. The reporting of this case as well as previous few reports from Kashmir valley clearly suggest that there is a need to evaluate the economic losses suffered by the small ruminant industry due to this infestation and map the prevalence of bot fly in Kashmir valley for development of suitable control measures.

\section{References}

12th Annual Report (2011-2012) Sher-e-Kashmir University of Agricultural Sciences \& Technology of Jammu. 55

Alcaide M, Reina D, Sanchez J, Frontera E, Navarrete I (2003) Seasonal variations in the larval burden distribution of Oestrus ovis in sheep in the southwest of Spain. Vet Parasitol 118:235-241

Bergeaud JP, Duranton C, Dorchies P (1994) Oestrus ovis in Eveyron: results of a study of 1036 sheep heads at the abattoir in Rodez. Revue de Med Vet 145:863-866

Caracappa S, Rilli S, Zanghi P, Di Marco V, Dorchies P (2000) Epidemiology of ovine oestrosis (Oestrus ovis Linne 1761, Diptera: oestridae) in Sicily. Vet Parasitol 92:233-237
Chhabra NG, Ruprah NS (1976) Observations on the incidence and biology of Oestrus ovis. Indian Vet J 53:180-184

Cobbett NG, Mitchell WC (1941) Further observations on the life cycle and incidence of the sheep bot, Oestrus ovis, in New Mexico and Texas. Am J Vet Res 2:358-366

Dorchies P, Duranton C, Jacquiet P (1998) Pathophysiology of Oestrus ovis infection in sheep and goats: a review. Vet Rec 142(18):487-489

Dorchies P, Bergeaud JP, Tabouret G, Duranton C, Prevot F, Jacquiet P (2000) Prevalence and larval burden of Oestrus ovis (Linne 1761) in sheep and goats in northern Mediterranean region of France. Vet Parasitol 88:269-273

Gupta SK (1982) Studies on some aspects of bionomics and treatment of Oestrus ovis Linnaeus 1758 in Sheep. Ph. D thesis submitted to Chaudhary Charan Singh Haryana Agricultural University, Hissar

Horak IG (1977) Parasites of domestic and wild animals in South Africa. I. Oestrus ovis in sheep. Onderstepoort J Vet Res 44(2):55-64

Jacquiet P, Dorchies P (2002) Towards a lower prevalence of Oestrus ovis infections in sheep in a temperate climate (South west France). Vet Res 33:449-453

Jagannath MS, Cozab N, Rahman SA, Honnapa TG (1989) Factors influencing Oestrus ovis infestation in sheep and goats. Curr Res 18:118-119

Shahardar RA, Rashid A (1998) Occurrence of larvae of Oestrus ovis in a goat in Kashmir Valley-A note. J Vet Parasitol 12:147

Shahardar RA, Darzi MM, Pandit BA (2001) Recovery of larvae of Oestrus ovis from trachea and bronchi of sheep. J Vet Parasitol 15(1):85

Sucilathangam G, Meenakshisundram A, Hariramasubramanian S, Anandhi D, Palaniappan N, Anna T (2013) External opthalmomyiasis which was caused by sheep bot fly (Oestrus ovis) larva: a report of 10 cases. J Clin Diagn Res 7(3):539-542

Taniya Saleem (2013) Epidemiology of Oestrus ovis in sheep and goats. MVSc. thesis submitted to Sher-e-Kashmir University of Agricultural Sciences \& Technology of Jammu

Wall R, Shearer D (1977) Veterinary entomology, arthropod ectoparasites of veterinary importance. Chapman and Hall, London

Yilma JM, Dorchies P (1991) Epidemiology of Oestrus ovis in southwest France. Vet Parasitol 40:315-323

Zumpt F (1965) Myiasis in man and animals in the old world. A textbook for physicians, veterinarians and zoologists. Butterworth, London, p 255 